\title{
中国外来入侵物种的分布与传入路径分析
}

\section{徐海根 ${ }^{1}{ }^{*}$ 强 胜 $^{2}$ 韩正敏 ${ }^{3}$ 郭建英 ${ }^{4}$ 黄宗国 $^{5} \quad$ 孙红英 ${ }^{6}$ 何舜平 ${ }^{7}$ 丁 晖 ${ }^{1}$ 吴海荣 $^{2}$ 万方浩 $^{4}$}

1( 国家环境保护总局南京环境科学研究所, 南京 210042)

2(南京农业大学杂草研究室, 南京 210095) 3(南京林业大学, 南京 210037)

4(中国农业科学院生物防治研究所, 北京 100081) 5(国家海洋局第三海洋研究所, 厦门 361005) 6(南京师范大学生命科学学院, 南京 210097) 7(中国科学院水生生物研究所, 武汉 430072)

摘要: 外来物种入侵已成为全球性的环境问题。本文采用文献调研、实地考察与专家咨询相结合的方式, 调查了全 国陆生、淡水水生生态系统中外来入侵微生物、无脊椎动物、两栖爬行类、鱼类、鸟类、哺乳类、杂草、树木和海洋生 态系统中外来入侵物种的种类及分类地位、起源、引入路径和环境影响等内容。查明我国共有 283 种外来入侵物 种, 其中外来入侵微生物、水生植物、陆生植物、水生无脊椎动物、陆生无脊椎动物、两栖爬行类、鱼类、哺乳类分别 为 19 种、18 种、170 种、25 种、33 种、3 种、10 种和 5 种; 来源于美洲、欧洲、亚洲、非洲、大洋洲的外来入侵物种分别 占 $55.1 \% 、 21.7 \% 、 9.9 \% 、 8.1 \%$ 和 $0.6 \%$ 。我国对外来物种的引进存在一定程度的盲目性: $50.0 \%$ 的外来入侵植物 是作为牧草或饲料、观赏植物、纤维植物、药用植物、蔬菜、草坪植物而引进的; $25 \%$ 的外来入侵动物是用于养殖、观 赏、生物防治的引种。对外来物种只重引进、疏于管理, 也可能导致外来物种逃逸到自然环境中, 造成潜在的环境 灾害。此外, 在检疫方面也存在很多薄弱环节, 所有外来入侵微生物是随引进的原木、幼树、苗木、花钵、土壤而无 意传入的; $76.3 \%$ 的外来入侵动物是由于检查不严, 随贸易物品或运输工具传入我国的。因此, 我国既要加强检疫 工作, 又要对外来物种的有意引进进行严格管理, 实行外来物种引进的风险评估制度。

关键词: 生物入侵, 原产地, 入侵途径

中图分类号：Q-9 文献标识码：A 文章编号：1005-0094(2004)06-0626-13

\section{The distribution and introduction pathway of alien invasive species in Chi- na}

XU Hai-Gen ${ }^{1 *}$, QIANG Sheng ${ }^{2}$, HAN Zheng-Min ${ }^{3}$, GUO Jian-Ying ${ }^{4}$, HUANG Zong-Guo ${ }^{5}$, SUN HongYing $^{6}$, HE Shun-Ping ${ }^{7}$, DING Hui ${ }^{1}$, WU Hai-Rong ${ }^{2}$, WAN Fang-Hao ${ }^{4}$

1 Nanjing Institute of Environmental Sciences, State Environmental Protection Administration, Nanjing 210042

2 Weed Research Laboratory, Nanjing Agricultural University, Nanjing 210095

3 Nanjing Forestry University, Nanjing 210037

4 Institute of Biological Control, Chinese Academy of Agricultural Sciences, Beijing 100081

5 Third Institute of Oceanography, State Oceanic Administration, Xiamen 361005

6 College of Life Sciences, Nanjing Normal University, Nanjing 210097

7 Institute of Hydrobiology, Chinese Academy of Sciences, Wuhan 430072

\begin{abstract}
Alien invasive species have become a serious environmental issue throughout the world. It is necessary to launch a nationwide investigation on alien invasive species, so as to obtain baseline data, identify causes of invasion, and put forward effective control strategies and measures. Data on classification, origin, pathway and environmental impacts of alien invasive micro-organisms, invertebrates, amphibians and reptiles, fish, birds, mammals, weeds, trees in terrestrial and aquatic ecosystems and alien invasive species in marine ecosystems of China were analyzed, based on literature research, field survey
\end{abstract}


and consultation. 283 alien invasive species have been identified in China, and the number of species of alien invasive micro-organisms, aquatic plants, terrestrial plants, aquatic invertebrates, terrestrial invertebrates, amphibians and reptiles, fish, and mammals were 19, 18, 170, 25, 33, 3, 10, and 5, respectively. The proportion of alien invasive species originating from America, Europe, Asia, Africa and Oceania were $55.1 \%, 21.7 \%, 9.9 \%, 8.1 \%$ and $0.6 \%$, respectively.

Many institutions and individuals in China lack adequate knowledge of ecological and environmental consequences caused by alien invasive species, with some blindness in the introduction of alien species. For instance, $50.0 \%$ of alien invasive plants were intentionally introduced as pasture, feed stock, ornamental plants, textile plants, medicinal plants, vegetables, or lawn plants. $25 \%$ of alien invasive animals were intentionally introduced for cultivation, recreation, or biological control. In addition, much effort has been made on introduction of alien species, and little attention has been paid to the management of introduced alien species, which may allow their escape into natural environments and potential threats to the environment. There are also gaps in the quarantine system in China. All invasive micro-organisms were unintentionally introduced, through timber, seedlings, flowerpots, or soil. $76.3 \%$ of alien invasive animals invaded through commodity or transportation facilities because of the failure of quarantine. It is recommended that quarantine measures should be strictly implemented. At the same time, the intentional introduction of alien species should be strictly managed and a system of risk assessment should be implemented.

Key words: biological invasion, invasive species origin, invasion pathway

虽然物种入侵与分布扩张在人类出现之前就是 地球史的一部分, 但人类活动加快了这种扩张的速 度。外来入侵物种被带入一个新的地区, 经过潜伏 期和归化期的生境适应后, 不断繁殖、扩展,一旦条 件适宜便可能暴发成灾,不仅严重损害经济作物,而 且破坏农田、水利工程, 对环境和经济发展造成极大 危害。例如, 在美国大约有 4500 种外来动植物建立 了自由生长的种群, 其中至少 675 种 (占 $15 \%$ ) 造成 了严重危害, 美国每年因外来入侵物种造成的经济 损失达 1380 亿美元 (Pimentel et al. , 2000)。外来 入侵物种对我国的工农业和生态系统、野生动植物 及遗传资源也造成巨大危害。例如, 松材线虫 (Bursaphelenchus xylophilus) 已逼近黄山、西湖; 松突 圆蚧 (Hemiberlesia pitysophila)、湿地松粉蚧 (Oracella acuta) 的危害仍在扩大; 凤眼莲 (Eichhornia crassipes) 在滇池危害十分严重; 薇甘菊 (Mikania micran$t h a$ ) 在局部地区暴发成灾。外来入侵物种是除生境 丧失外威胁全球生物多样性的最重要因素之一, 并 将产生两种值得关注的全球效应: 降低动植物区系 的独特性和打破维持全球生物多样性的地理隔离 (Lovei, 1997; 方炜, 2000)。因此, 加强对外来入侵 物种的研究和防除刻不容缓。

一些国际公约要求其缔约国开展外来入侵物种 的防治工作。例如, 《生物多样性公约》第 8 条 $\mathrm{h}$ 款 要求缔约国尽可能“防治、控制或消除那些威胁到
生态系统、生境或物种的外来物种”。世界上一些 国家已经制定了预防、控制和消除外来入侵物种的 法规, 如美国的《联邦植物病虫害法》、《联邦有害杂 草法》、《外来有害水生生物预防和控制法》、《国家 入侵物种法》等; 新西兰也颁布了《生物安全法》。 然而, 我国对外来入侵物种的底数不清、认识不足、 控制不严。因此需要在全国范围内开展外来入侵物 种调查, 以便查清现状, 明确入侵原因, 提出有效的 防治对策和措施。本文在全国外来入侵物种调查的 基础上, 分析了外来入侵物种在我国的种类分布及 其传入路径。

\section{1 全国外来入侵物种调查}

外来入侵物种是指出现在其过去和现在的自然 分布范围以外的、在本地的自然或半自然生态系统 或生境中形成了自我再生能力、给本地的生态系统 或景观造成明显损害或影响的物种。外来入侵物种 的分类阶元主要是种和亚种, 也包括种子、卵、孢子 或其他形式的能使种族繁衍的生物材料。全国外来 入侵物种的调查主要限于从其他国家进入我国的外 来入侵物种。

\section{1 调查对象}

本次调查的对象包括外来入侵微生物、无脊椎 动物、两栖爬行类、鱼类、鸟类、哺乳类、杂草、树木、 海洋生物等。 


\section{2 调查的区域}

全国外来入侵物种调查范围为全国的陆生、淡 水水生和海洋生态系统。

\section{3 调查指标体系}

本次调查采用统一的调查指标, 共有 20 项, 涉 及外来入侵物种的分类、形态、分布、首次发现或引 入的地点及时间、起源、入侵途径、生境、生活史、影 响和防治措施等内容。包括:

(1) 学名: 外来入侵物种的拉丁文名称。

(2) 中文名:外来入侵物种的中文名称。

(3) 英文俗名: 外来入侵物种的英文通俗名称。

（4）分类地位: 外来入侵物种所属的纲、目、科 的中文和拉丁文名称。

（5）生态类群: 指外来入侵物种所属的生态类 群, 包括微生物、陆生无脊椎动物、水生无脊椎动物、 两栖类、爬行类、鱼类、鸟类、哺乳类、陆生植物、水生 植物等。

（6）形态性状: 描述外来入侵物种的形态性状。

（7）种群建立状况: 指外来入侵物种在自然或 半自然生态系统中的建立状况,包括已建立种群、未 建立种群或不清三种状态。

（8）分布范围: 指外来入侵物种在自然生态系 统中的分布范围。

（9）经济和生态影响: 指外来入侵物种对工业、 农业、林业、渔业、牧业、旅游业和生态系统造成的不 利影响及其经济损失, 包括损失的面积和经济价值。

(10) 首次发现或引入的地点及时间: 指外来入 侵物种首次被发现或引入国内的地点及时间。

（11）起源: 指外来入侵物种起源于哪个国家或 地区。

（12）引入路径:一是有意引进,包括用于养殖、 种植、花卉等目的的引种, 用于生物防治、绿化、水土 保持、环境保护等目的的引进; 二是无意引进,包括 随航空、陆路、水路运输工具和压舱水的引入, 随进 出口货物和包装材料的引入,旅客无意引入等; 三是 自然入侵。

（13）入侵途径: 指外来入侵物种在本地扩散的 途径, 如随交通工具传播, 随风、虫和鸟等媒介传播, 自我扩散, 人为携带, 以及影响扩散的因素。

（14）生境类型: 指外来入侵物种的栖息地类 型, 包括农田、荒漠、森林、草原、冰川、灌丛、冻原、内 陆水域和湿地、海岸和海洋等。
（15）生活史: 指外来入侵物种的生殖方式、生 命周期和危害发生规律。

（16）营养和环境条件: 指外来入侵物种生存所 需的营养和环境条件; 外来入侵物种的营养来源, 外 来入侵物种危害发生的条件。

(17) 可能扩散的区域: 指外来入侵物种今后可 能扩散的地区。

（18）预防、控制和管理措施: 指预防、控制、消 除外来入侵物种及生态恢复的现有技术和措施。

（19）图片: 描述外来入侵物种性状或危害状况 的图片。

(20) 参考资料: 数据的资料来源, 如参考文献、 网址等。

\section{4 调查方式}

采用文献调研、实地考察与专家咨询相结合的 方式。

\section{2 全国外来入侵物种调查数据汇总分析}

本次调查从 2001 年 12 月开始,有来自农业、林 业、海洋、水产、科研和教育等部门的 20 余人参与, 历时近 2 年时间, 于 2003 年 10 月基本结束。本次 调查查明了 283 种外来入侵物种的分类地位、起源、 引入路径、生态和经济影响等详细信息, 并建立了数 据库。查明外来入侵微生物 19 种, 占中国外来入侵 物种总数的 $6.7 \%$; 水生植物 18 种, 占总种数的 $6.4 \%$; 陆生植物 170 种, 占总种数的 $60.0 \%$; 水生 无脊椎动物 25 种, 占总种数的 $8.8 \%$; 陆生无脊椎 动物 33 种, 占总种数的 $11.7 \%$; 两栖爬行类 3 种, 占总种数的 $1.1 \%$; 鱼类 10 种, 占总种数的 $3.5 \%$; 哺乳类 5 种, 占总种数的 $1.8 \%$ (图 1 )。从调查结果 分析, 外来入侵物种中, 一半以上是陆生植物; 其次 是陆生无脊椎动物、水生无脊椎动物和微生物; 水生 植物位居第五。

在这些外来入侵物种中, 来自美洲的有 178 次, 占总频次的 $55.1 \%$ (原产地总频次为 323 ); 来源于 欧洲的有 70 次, 占总频次的 $21.7 \%$; 来自亚洲的有 32 次, 占总频次的 $9.9 \%$; 来自非洲的有 26 次, 占总 频次的 $8.1 \%$; 来源于大洋洲的有 2 次, 占总频次的 $0.6 \%$ (图 2)。

在 283 种外来入侵物种中, $39.6 \%$ 属于有意引 进, $49.3 \%$ 属无意引进; 经自然扩散而进入中国境内 的外来入侵物种仅 9 种, 占 3.1\% (图 3)。 


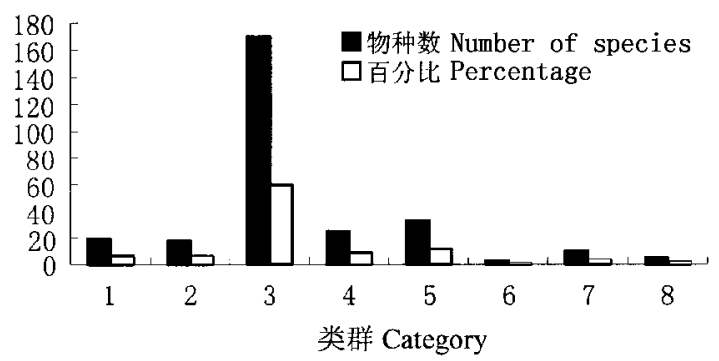

图 1 中国外来入侵物种的类群

Fig. 1 Ecological categories of alien invasive species in China 1: 微生物; 2 : 水生植物; 3 : 陆生植物; 4 : 水生无脊椎动 物; 5: 陆生无脊椎动物; 6: 两栖爬行类; 7: 鱼类; 8: 哺乳 类

1, Microorganism; 2, Aquatic plant; 3, Terrestrial plant; 4, Aquatic invertebrate; 5, Terrestrial invertebrate; 6, Amphibian and reptile; 7, Fish; 8, Mammal

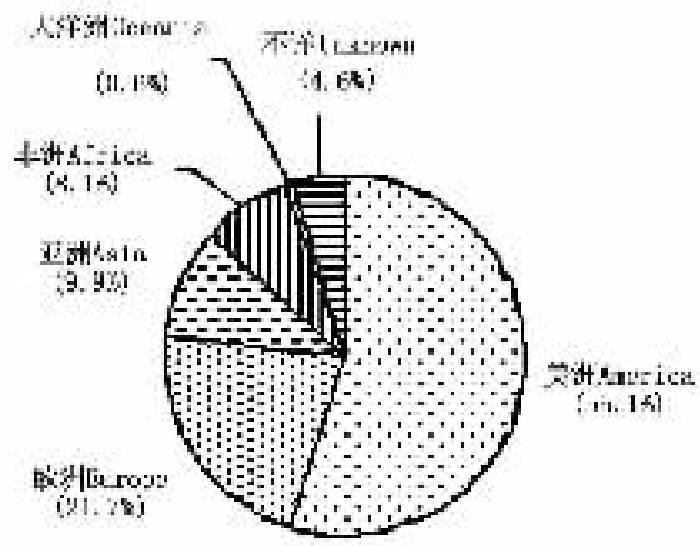

图 2 中国外来入侵物种的原产地

Fig. 2 The origins of alien invasive species in China

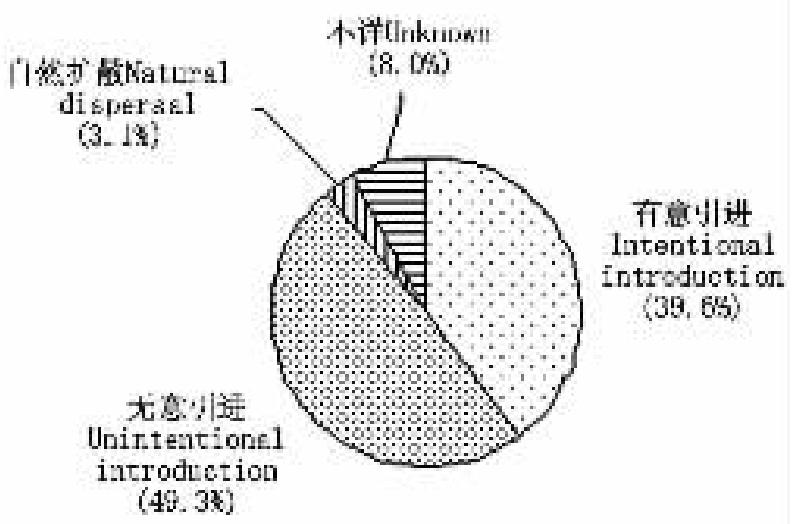

图 3 中国外来入侵物种的引入路径

Fig. 3 Introduction pathways of alien invasive species in China

外来入侵物种的主要生境类型是农田生态系
统, 达 $59.1 \%$; 其次是森林生态系统和海洋生态系 统, 分别占 $13.7 \%$ 和 $12.5 \%$ (图 4)。农田生态系统 实际上是一个人工生态系统, 受人为干扰大, 容易受 到外来物种的入侵。但森林、海洋、内陆水域和湿地 也同样遭受着外来入侵物种的危害, 也应引起高度 重视。

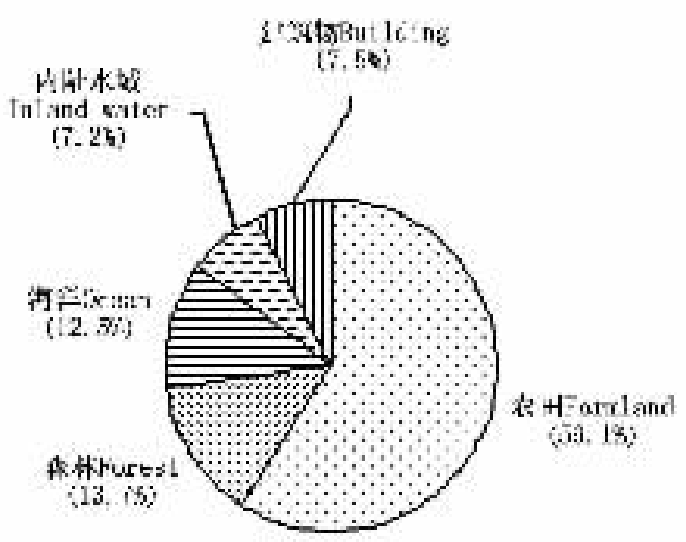

图 4 中国外来入侵物种的生境类型

Fig. 4 Habitats of alien invasive species in China

在此分析基础上来确定 100 种主要外来入侵物 种。满足以下条件之一的入选: (1) 有很强或较强 的入侵性,已在全国或部分省份广泛分布; (2) 造成 严重或较大危害; (3) 防治或清除有一定的难度。 明确入选条件后, 向国内农业、林业、海洋、水产、环 保、科研、教育等部门的 15 位专家发出咨询信, 请这 些专家遴选主要外来入侵物种, 信中提供 283 个外 来入侵物种的名录及简单介绍, 并分配各类群的名 额: 微生物 10 种; 水生植物 10 种; 陆生植物 40 种; 水生无脊椎动物 12 种; 陆生无脊椎动物 18 种; 两栖 爬行类 2 种; 鱼类 4 种; 哺乳类 4 种。对专家意见进 行综合分析后, 确定了 100 种主要外来入侵物种 ( 附录 1 )。

\section{3 外来入侵微生物}

目前中国共有外来入侵微生物 19 种, 分别隶属 丝狍科 ( Hyphomycetaceae)、瘤座狍科 ( Tuberculariaceae)、暗梗狍科 (Dematiaceae)、黑盘孢科 (Melanconiaceae)、丛梗孢科 (Moniliaceae)、假单胞菌科 (Pseudomonaceae)、集壸菌科( Synchytriaceae)、明盘 菌科( Hyaloscyphaceae)、座囊菌科 (Dothideaceae)、 栅锈科 (Melampsoraceae) 、间座壳科 (Diaporthace- 
ae)、长喙霉科 ( Ceratocystiaceae)、腐霉科 ( Pythiace$a e$ )、霜霉科 ( Peronosporaceae)、豇豆花叶病毒科 (Comoviridae)、香石竹潜隐病毒属 (Carlavirus)、棒 形杆菌属（Clavibater）, 其中假单胞菌科 3 种, 其他 均为 1 种。

在 19 种外来入侵微生物中, 9 种来源于美洲, 包括松针红斑病菌 (Mycosphaerella pini)、桉树青枯 病菌（Pseudomonas solanacearum）、桉树焦枯病菌 (Cylindrocladium scoparium) 、落叶松癌肿病菌 (Lachnellula willkommii)、杨树花叶病毒 (Carlavirus sp. )、甘薯长潒壳菌 (Ceratocystis fimbriata)、大豆疫 病菌 (Phytophthora megasperma)、番茄细菌性溃疡病 菌( Clavibater michiganensis)、棉花黄萎病菌( Verticillium dahliae), 占我国外来入侵微生物总种数的 $47.4 \%$; 种起源于欧洲, 包括香石竹枯萎病菌 $(F u$ sarium oxysporum) 、油橄榄癌肿假单狍杆菌 (Pseudomonas savastanoi)、杨树大斑溃疡病菌 (Cryptodiaporthe populea)、松疮锈病菌 (Cronartium ribicola), 占 我国外来入侵微生物总种数的 $21.1 \%$; 来自亚洲的 有 1 种, 为起源于日本的落叶松枯梢病菌 (Botryosphaeria laricina)。其他外来入侵微生物的来源地 尚不清。

外来入侵微生物一般是随新鲜带皮的原木、接 穗或带有小枝的原木、幼树、苗木、花钵、土壤而无意 传入的, 均属无意引进。一方面是由于人们对微生 物的知识还很缺乏, 对微生物的鉴别能力还很低; 另 一方面由于微生物个体很小, 常隐藏在寄主体内或 货物中,不易被检验和发现。

\section{4 外来入侵植物}

\section{1 外来入侵植物的种类构成}

经过调查研究和对大量文献资料的整理分析, 目前中国共有外来入侵植物 188 种, 其中水生植物 18 种, 陆生植物 170 种, 隶属 41 科。种数最多的科 是菊科 (49 种) 和禾本科 (33 种), 其他种数较多的 科有: 豆科 14 种、苋科 11 种、茄科 7 种、玄参科 5 种, 大戟科、伞形科各 4 种, 十字花科、石竹科、葫芦 科、旋花科、锦葵科、仙人掌科均为 3 种。

\section{2 外来入侵植物的来源地分析}

在 188 种外来入侵植物中, 来自美洲的有 125 种, 占中国外来入侵植物总种数的 $66.5 \%$; 来源于 欧洲的有 45 种, 多为适宜于温凉气候条件的杂草种
类(强胜和曹学章, 2000 ); 来源于亚洲的有大麻 (Cannabis sativa)、白香草木樨( Melilotus albus) 和节 节麦( Aegilops squarrosa) 等 22 种; 起源于非洲的有 野西瓜苗(Hibiscus trionum) 等 17 种; 起源于大洋洲 的 1 种, 即裸柱菊 (Soliva anthemifolia)。

从上面的分析不难看出, 美洲起源的外来植物 所占比例最大, 占一半以上, 这说明美洲的植物较能 适应中国的生境。在以后的植物引种中, 要特别注 意来自美洲新大陆的植物 (强胜和曹学章,2000)。

\section{3 外来入侵植物的传入路径}

(1) 作为有用植物而引进

在 188 种外来入侵植物中,有 94 种是作为有用 植物而引进的, 占 $50.0 \%$ 。其用途又可细分为: 牧 草或饲料、观赏植物、纤维植物、药用植物、蔬菜、草 坪植物、环境植物等( 强胜和曹学章, 2000)。

(2) 从邻国自然扩散或随交通工具传播进入

紫茎泽兰 (Eupatorium adenophorum) 大约于 20 世纪 40 年代由泰国经缅甸和越南传入中国的云南; 豚草 (Ambrosia artemisiifolia) 和三裂叶豚草 (A. trifi$d a)$ 可能是在 20 世纪 30-40 年代由北美经苏联传 入东北, 交通工具可能是其传播的主要方式, 交通发 达地区特别是交通沿线是其发生分布的主要区域 （强胜和曹学章,2000）。

(3) 由国际农产品和货物的输入裹挟带入或由 船只压舱水带入

假高粱 (Sorghum halepense) 是 20 世纪 70-80 年代从美洲国家的进口粮食中夹杂传入的 (强胜和 曹学章, 2000 ); 洞刺角刺藻 (Chaetoceros concavicor$n i s$ )、新月圆柱藻 (Cyclindrotheca closterium) 、方格直 链藻( Melosiar cancellate) 、柔弱菱形藻 (Nitzschia deicatissima)、微缘羽纹藻 ( Pinnularia viridis)、微型原 甲藻 ( Prorocentrum minimum) 、反屈原甲藻 ( P. sigmoides)、波罗的海原甲藻 (Perocentrum balticum) 、冰 河星杆藻 ( Alexandrum catenclla) 、斯氏梨形藻 (Scrippsiella trochoidea)、多甲藻 ( Peridinium perardiforme) 等 11 种藻类是由船只压舱水带入的 (黄宗 国，1994; 国家海洋局,2001; 张硕慧，2002）。

(4) 随植物引种带入

田野毛茛( Ranunculus arvensis)、阿拉伯婆婆纳 (Veronica persica)、毒麦 (Lolium temulentum) 、长芒毒 麦 ( L. temulentum var. longiaristatum) 等可能是在麦 类引种过程中带入的( 强胜和曹学章,2000)。 
当然, 这些传入路径有可能是相互交叉的, 同一 种杂草可能是经过一种以上的途径传入的, 而在时 间上也可能是多次的输入, 最终定植并得到迅猛发 展( 强胜和曹学章,2000)。

\section{5 外来入侵动物}

5.1 外来入侵动物的种类构成

根据调查, 我国共有外来入侵动物 76 种, 其中 水生无脊椎动物 25 种, 陆生无脊椎动物 33 种, 两栖 爬行类 3 种,鱼类 10 种, 哺乳类 5 种。种数最多的 是苔藓虫 13 种, 其次是鼠科、豆象科各 4 种, 藤壶 科、蛙科各 3 种, 滑刃科、瘞蚊科、粉䖝科、麦蛾科各 2 种。

\section{2 外来入侵动物的来源地分析}

在 76 种外来入侵动物中, 来自美洲的有 44 种, 占中国外来入侵动物总种数的 $57.9 \%$ 。其中来自 北美的有克氏原螯虾 ( Procambarus clarkii) 、曼氏皮 海鞘 (Molgula manhattensis)、冠瘤海鞘 (Styela canopus)、松材线虫 (Bursaphelenchus xylophilus)、湿地松 粉蚧（Oracella acuta）、苹果绵蚜（Eriosoma lanigerum)、四纹豆象 (Callosobruchus maculates)、美国 白蛾 (Hyphantria cunea)、稻水象甲 (Lissorhoptrus oryzophilus)、红脂大小冨 (Dendroctonus valens)、牛蛙 (Rana (Aquarana) catesbeiana)、鹿鼠 (Ondatra zibeth$i c a$ ) 等; 来自中美洲的有沙饰贝 (Mytilopsis sallei)、 指甲履螺 (Crepidula onyx) 等; 来自南美洲的有福寿 螺 ( Pomacea canaliculata)、獭狸 (Myocastor coypus) 等。来源于欧洲的有 21 种, 占我国外来入侵动物总 种数的 $27.6 \%$, 如菊花叶枯线虫 (Aphelenchoides ritzemabosi)、豌豆象 (Bruchus pisorum)、䖯豆象 ( B. rufimanus)、小家鼠( Mus musculus) 等; 来自非洲的 有 9 种, 如非洲大蜗牛 (Achatina fulica)、奥利亚罗 非鱼 (Oreochromis aureus) 等; 来自亚洲的有 9 种, 如 韦氏团水闽( Sphaeroma walkexi)、日本松干蚧 ( Matsucoccus matsumurae)、松突圆蚧 (Hemiberlesia pitysophila)、谷斑皮蛽( Trogoderma granarium)、双钩异 翅长蛽 (Heterobostrychus aequalis)、褐家鼠( Rattus norvegicus norvegicus) 等。

从上面的分析不难看出, 美洲起源的外来入侵 动物所占比例最大, 占一半以上, 这可能有两大原 因。其一, 美洲动物较能适应中国的生境。其二, 近 年来我国与美洲、欧洲和亚洲在经贸旅游等方面交
流相对较多,但我国与亚洲和欧洲之间的物种渗透 也较多, 达到了相对平衡, 与美洲的经贸旅游交流活 动造成外来动物的入侵。

\section{3 外来入侵动物的传入路径}

在 76 种外来入侵动物中, 有意引进的有 19 种, 占我国外来入侵动物总种数的 $25 \%$; 无意引进的有 58 种, 占我国外来入侵动物总种数的 $76.3 \%$; 自然 扩散的有 1 种。

\subsection{1 有意引进}

(1) 用于养殖、观赏、生物防治的引种

福寿螺 ( Pomacea canaliculata)、克氏原螯虾、牛 蛙、獭狸等外来入侵物种主要是出于养殖、观赏等目 的引进到国内, 因野生放养或弃养后, 在野外形成自 然种群, 对动物区系中的土著种造成一定的危害, 并 对当地的农业经济造成一定影响。例如福寿螺在 20 世纪 80 年代初被引入中国, 在台湾、福建、广东、 广西、海南等省饲养, 由于养殖效益不佳而放弃管 理, 导致其迅速蔓延, 进入农田、水沟、池塘, 逸为野 生; 1987 年,福寿螺被引入四川,在沪州等地形成田 间自然种群( 冯伟明, 1994; 吴志平和程开禄, 1995; 蔡汉雄和陈日中, 1990)。牛蛙是我国最早引入的 养殖蛙类, 它具有个体大、生长快、肉味鲜美等特点。 1959 年从古巴引进后, 先后在 20 多个省市推广养 殖, 由于一些地区的养殖管理不善, 以及实行稻田、 菜地等自然放养而逸为野生( 陈素芝, 1993)。

我国的鱼类外来物种有两个来源: 一是水产品 种的引进, 二是观赏鱼的引进。我国 10 种较为典型 的鱼类入侵物种如奥利亚罗非鱼 (Oreochromis aureus)、尼罗罗非鱼 (O. nilotica)、斑点叉尾鮰 ( Ictalurus punctatus)、大口黑鲈( Micropterus salmoides)、大 口胭脂鱼 (Ictiobus cypinellus)、虹鳟( Oncorhynchuo mykiss)、短盖巨脂鲤 (Colossoma brachypomum)、革胡 子鮎 (Clarias lazera)、路斯塔野鲮 (Labeo rohita), 绝 大多数都是作为养殖新品种从世界各地引进的。这 些外来物种逃逸到自然水体后, 适应了环境并能自 然繁殖后就成为入侵物种。比如来自非洲的尼罗罗 非鱼在我国云南、广西就有自然种群。一般说来, 水 产养殖推广的品种, 如适应性强就很容易建立种群 成为入侵种。而水族观赏鱼因种群小, 成为入侵种 的可能性较小。食蚊鱼 (Gambusia affinis) 是出于生 物防治的目的而引进的, 1911 年引入我国台湾, 1924 年进入内地, 并在很多省市自然繁殖 (李振宇 
和解炎, 2002)。

獭狸在 1953 年被引入我国东北, 在动物园内饲 养, 供观赏用。由于獭狸具有浓密柔软的线毛, 其保 温性能优于水獭, 曾被视为珍稀毛皮动物, 1986 年 起在我国各地推广养殖。但是, 由于獭狸在南方饲 养后毛质变差, 养大后的獭狸因无人问津而被弃养, 逸为野生( 许瑞秋, 1997)。

(2) 随引进树木接穗、苗木或盆景而传入

日本松干蚧于 1903 年由日本昆虫学家桑名伊 三吉在日本东京庭园的黑松 (Pinus thunbergii)上发 现，随引进松树接穗、苗木或盆景而从日本传入我国 （郑汉业，1979; 李桂和，1980; 林业部保护司和森 防总站, 1996; 高步鹳, 1998)。湿地松粉蚧主要以 若虫危害湿地松 (Pinus elliottii) 的松梢、嫩枝及球 果, 受害松梢轻者抽梢和针叶伸展长度明显减少, 严 重时梢上针叶极短或顶芽枯死、弯曲, 形成从枝。它 是 1988 年在引进湿地松优良无性系穗条时, 未经检 疫处理而不慎从美国佐治亚州带入的。1990 年 6 月, 湿地松粉蚧首次在广东省台山市红岭湿地松种 子园松梢上被发现 (潘务耀等, 1995; 庞雄飞和汤 才, 1994; 徐家雄等, 1992)。葡萄根瘤䖮( Viteus vitifoliae) 是 1892 年随引种苗木传入山东烟台的 (北 京农业大学，1989; 曹骥,1988)。

美国白蛾是一种寄主种类杂、繁殖能力强、适生 范围广、传播速度快、危害严重、防治难度大的世界 性检疫害虫。1979 年, 在中朝边境地区开展农作物 病虫调查时, 首次在丹东市发现。该虫原发生于北 美, 广布在美国、加拿大南部和墨西哥局部地区 (美 国 40 个州, 加拿大 8 个省和地区, 墨西哥的维拉克 鲁斯州)。我国主要有三种引入途径, 其中一个途 径是随引进的花卉而传入的 (屈邦选, 1987; 高步 忂, 1998）。

\subsection{2 无意引进}

外来动物入侵的另一个途径是在贸易交流时, 由于检查不严格, 随产品进入我国, 随后发展成为野 生。如松材线虫、红脂大小蛽、美国白蛾、小家鼠、屋 顶鼠 (Rattus rattus rattus) 和褐家鼠。

几种主要虫害均是通过木质包装箱、木材及木 制品而传入的, 近年来有增加之势。松材线虫主要 侵染松类植物, 引起松树枯萎死亡, 是松树的一种毁 灭性病害。我国于 1982 年在南京中山陵风景区首 次发现松材线虫, 它是由南京紫金山天文台从日本
进口的光学仪器包装箱中携带的松材线虫传播介体 松墨天牛( Monochamus alternatus) 而引入的( 叶 为民，1993)。红脂大小蠹 1998 年 9 月在我国山西 省晋城市沁水、阳城等县的部分油松林内首次被发 现, 它是随带皮的进口松材引入的 (苗振旺, 2001; 殷惠芬, 2000; 段东红和高晋东, 2000; 宋玉双, 2000 )。美国白蛾的另一种传入途径是随进出口货 物和包装材料引入。

华美盘管虫 (Hydroides elegans)、沙饰贝、指甲 履螺、象牙藤壶 (Balanus eburneus) 、致密藤壶 (B. improvisus)、纹藤壸 (B. amphitrite)、韦氏团水闽、苔 藓虫 (Bryozoa)、玻璃海鞘 (Ciona intestinalis)、曼氏 皮海鞘、冠瘤海鞘等海洋外来入侵动物是靠附着于 船底长距离传播而进入的 (黄宗国, 1994; 黄宗国和 蔡如星, 1984)。小家鼠、屋顶鼠和褐家鼠通常利用 轮船、火车为其栖居场所, 由外轮输入我国沿海城市 (訤继忠和徐军, 1994; 㚞德海,2001)。

\subsection{3 自然扩散}

我国外来入侵动物中仅有鹿鼠 1 种是通过自身 的扩散或借助于河流、风力等自然力量而传入, 即自 然入侵。

鹿鼠原产北美, 以后引入欧洲各国, 1927 年从 北美洲引入前苏联, 经人工放养遍及前苏联各地, 分 别沿着西北和东北两端边境的河流自然扩散至我国 境内 (程大生, 1986)。西北角经伊犁河、额尔齐斯 河扩散到新疆; 东北角经黑龙江 (在前苏联境内称 阿穆尔河) 和乌苏里江两条界河扩散到黑龙江省。 1953 年在新疆北部伊犁河中发现, 随后在黑龙江省 有正式报道。1958 年起从新疆捕捉活鼠 7000 余只 在全国 10 多个省区散放养殖 (马逸清, 1980; 朱靖 和严志堂, 1964,1965; 程大生, 1986)。

当然, 有的外来入侵动物可以通过多种途径成 功入侵。外来动物的成功入侵往往不是一次输入的 结果, 而可能是 2 次或多次输入的结果。大连港于 $1958-1959$ 年曾在港区捕捉屋顶鼠 4 只, 该码头曾 停靠从黑海驶来的前苏联货轮数艘次, 经确认屋顶 鼠系泊来种。1960 年以后连年监测再未捕到。 $1985-1990$ 年大连港拆除买自俄罗斯的废钢船 45 艘,这些废钢船均来自越南、印度以及黑海、非洲等 港口, 在此期间, 共检出屋顶鼠 125 只 (樊德海, 2001）。4 年之后, 在港区生活区又捕到屋顶鼠 2 只 (1 成体、 1 幼体)。这一事例提示, 多次外轮的输入 
可能是外来屋顶鼠能够成功入侵我国沿海城市的重 要因素之一。

\section{6 讨论}

随着国际经济交往的日益频繁和交通的便利, 原有的地理阻隔因素在逐渐消除，世界各地间物种 的交流和渗透在日益加剧, 外来物种入侵的风险也 随之增加 (陈良燕和徐海根, 2001)。外来入侵物种 通过压制或排挤本地物种, 形成单优势种群, 危及本 地物种的生存, 加快物种的消失与灭绝( 强胜和曹 学章, 2001; 万方浩等, 2002; 徐承远等, 2001; 李博 等, 2001), 破坏生态系统的结构和功能(张林艳和 叶万辉, 2002; 梁玉波和王斌, 2001; 彭少麟和向言 词, 1999), 已造成巨大经济损失 (Pimentel et al., 2000; 万方浩等,2002)。

人们对外来物种可能导致的生态和环境后果缺 乏足够的认识, 对外来物种的引进存在一定程度的 盲目性,往往没有经过严格的科学论证。有些地方 和部门盲目认为引进的植物比本地的好, 因此不注 意发掘本地的优良品种,而热衰于从国外引种, 极大 地增加了外来物种入侵的风险。例如, 在 188 种外 来入侵植物中, $50.0 \%$ 即 94 种是作为牧草或饲料、 观赏植物、纤维植物、药用植物、蔬菜、草坪植物而引 进的; $25 \%$ 的外来入侵动物是用于养殖、观赏、生物 防治的引种, 或有意引进树木接穗、苗木或盆景而传 入。另外, 外来物种只重引进而疏于管理, 也可能导 致外来物种从栽培地、驯养地逃逸到自然环境中而 演化为具有入侵性的物种, 造成潜在的环境灾害。

我国涉及外来物种管理的法律主要有《卫生防 疫法》、《进出境动植物检疫法》、《动物防疫法》和 《野生动物保护法》等, 尚未出台有关外来物种预 防、引进、控制的专项法规，使得外来物种的管理缺 少法律依据。现有法律在预防外来入侵物种的无意 传入和疫情控制方面作了较为具体的规定, 并建立 了水生和陆生野生动物引进的审批制度, 但没有规 定有意引进外来物种必须实行科学的风险评估制 度。而且，检疫对象侧重于那些对农、林、牧、渔业带 来危害的危险性生物, 但对于那些可能对生态环境、 生物多样性构成威胁的外来入侵物种则没有予以重 视 ( 徐海根和丁晖,2003)。所有外来入侵微生物均 是随新鲜带皮的原木、接穗或带有小枝的原木、幼 树、苗木、花针、土壤而无意传入的; $76.3 \%$ 的外来入
侵动物是由于检查不严, 随贸易物品或运输工具传 入我国的。

外来入侵物种防治, 既要重视对无意引进外来 入侵物种的预防工作，严格检疫，把好国门关; 另一 方面, 又要对外来物种的有意引进进行严格管理 (梁晓东和叶万辉, 2001), 实行外来物种引进的风 险评估制度，只有经过风险评估证明是安全的外来 物种才能放行 (徐海根和丁晖,2003)。为此建议:

(1) 建立健全法律法规, 实现依法管理。新建 《生物安全法》, 对外来物种风险评估、预警、引进、 控制、消除、生态恢复、赔偿责任等作出明确规定, 特 别要加强农业、林业、养殖业等有意引进外来物种的 管理，并建立外来入侵物种的名录制度、风险评估制 度, 在环境影响评价制度中增加有关外来物种入侵 风险分析的内容。修改《进出境动植物检疫法》中 的危险性生物名录, 增补对生态环境、生物多样性构 成威胁的外来入侵物种或可能构成威胁的潜在外来 入侵物种。

(2) 加强外来物种风险评估的能力建设。外来 物种入侵, 往往产生不可逆转的严重后果。因此, 必 须坚持“预防为主，防治结合” 的方针, 从源头上防 止外来物种的入侵。要做好潜在入侵物种的风险分 析,特别要重视其对我国生态环境和生物多样性的 影响, 建立和完善外来物种的风险评估制度。要进 一步加强和完善外来入侵物种的调查和环境影响监 测, 完善外来入侵物种的检验检疫方法和手段。

（3）进一步加强跨部门协调机制, 加强信息交 流。外来入侵物种管理涉及到多个部门, 应进一步 加强部门协调, 加强外来入侵物种发生、发展和暴发 的信息交流，要重视对境外外来入侵物种发生、发展 和暴发的情报分析, 建立数据库和早期预警系统, 发 布预警名录。

(4) 加强与防治外来物种入侵有关的科学研 究。全面研究外来物种入侵的机理及其危害发生、 发展和暴发的规律; 研究建立外来入侵物种的风险 评价和风险管理技术体系; 研究建立外来入侵物种 检疫检测、环境监测和预测预报的技术平台以及信 息网络和数据库系统; 研究建立外来入侵物种的可 持续控制技术和环境友好组合控制技术。

（5）加强公众教育, 提高公众意识。广泛宣传防 治外来入侵物种的相关知识, 提高全民防范意识, 减 少对外来入侵物种的有意或无意引进。 
(6)加强财政投入, 促进外来入侵物种防治。 国家应从财政预算中拨出专款, 用于外来入侵物种 的预防、控制、清除、科学研究和公众教育。

\section{参考文献}

Beijing Agricultural University (北京农业大学)．1989. Plant Quarantine (second manual) (植物检疫学(中册)). Beijing Agricultural University Press, Beijing. (in Chinese)

Cai, H. X. (蔡汉雄) and Chen, R. Z. (陈日中). 1990. A new pest-apple snail. Guangdong Agricultural Science(广 东农业科学), (5): 36-38. ( in Chinese)

Cao, J. (曹瀷). 1988. Manual of Plant Quarantine (植物检疫 手册). Science Press, Beijing. (in Chinese)

Chen, L. Y. (陈良燕) and Xu， H. G. (徐海根). 2001. Australian management strategy for invasive alien species and references available to China. Biodiversity Science (生 物多样性), 9: 466 -471. (in Chinese with English abstract)

Chen, S. Z. (陈素芝). 1993. Preliminary study on introduced frogs in China. Chinese Journal of Zoology (动物学杂志), 28(2) : 12 - 14. (in Chinese with English abstract)

Cheng, D. S. (程大生). 1986. Discussion on the origin of muskrat in Xinjiang. Wildlife (野生动物), 7(5)：52. (in Chinese with English abstract)

Department of Wild Animal and Plant Conservation and General Station of Forest Pest and Disease Prevention of Ministry of Forestry (林业部保护司和森防总站). 1996. Objective of Forest Plant Quarantine in China (中国森林植物检疫对 象). China Forestry Publishing House, Beijing. (in Chinese)

Duan, D. H. (段东红) and Gao, J. D. (高晋东). 2000. The principle and strategy for the prevention of red turpentine bark beetle. Forestry of Shanxi (山西林业), (5): 23 -24. (in Chinese with English abstract)

Fan, D. H. (樊德海). 2001. Black rat found in the boatyard of Dalian Marine University. Chinese Journal of Vector Biology and Control (中国媒介生物学及控制杂志), 12(3): 212. (in Chinese with English abstract)

Fan, J. Z. (樊继忠) and Xu, J. (徐军). 1994. The study on the propagating law of the Rattus norvegicus family. Chinese Journal of Vector Biology and Control (中国媒介生物学及 控制杂志)，5(4)：260-262. (in Chinese with English abstract)

Fang, W. (方炜). 2000. Biological invasion and global change. In: Fang, J. Y. (方精云) (ed. ), Global Ecolo- gy: Climatic Change and Ecological Response ( 全球生态 学: 气候变化与生态响应). Higher Education Press, Beijing. (in Chinese)

Feng, W. M. (冯伟明). 1994. The biological trait and prevention of apple snail. Guangdong Agricultural Science (广 东农业科学)，(6)：41-42. (in Chinese)

Gao，B. Q. (高步嘼). 1998. Forest Plant Quarantine( 森林植 物检疫). China Science and Technology Press, Beijing. ( in Chinese)

Huang, Z. G. (黄宗国) and Cai, R. X. (蔡如星). 1984. Marine Biofouling and Its Prevention and Control (海洋污 损生物及其防除). Ocean Press, Beijing. (in Chinese)

Huang, Z. G. (黄宗国). 1994. Species and Distribution of Marine Organisms in China (中国海洋生物种类与分布). Ocean Press, Beijing. (in Chinese)

Li, B. (李博), Hsu, P. S. (徐炳声) and Chen, J. K. (陈家 宽). 2001. Perspectives on general trends of plant invasions with special reference to alien weed flora of Shanghai. Biodiversity Science (生物多样性)，9: 446 - 457. (in Chinese with English abstract)

Li，G. H. (李桂和). 1980. Study on the Prevention and Control of Pine Bast Scale (松干蚧防治技术的研究). Science and Technology Literature Press, Beijing. (in Chinese)

Li，Z. Y. (李振宇) and Xie, Y. (解炎). 2002. Invasive Alien Species in China (中国外来入侵种). China Forestry Publishing House , Beijing. (in Chinese)

Liang, X. D. (梁晓东) and Ye, W. H. (叶万辉). 2001. Management strategies for invasive species in the United States. Biodiversity Science (生物多样性), 9: 90 - 94. (in Chinese with English abstract)

Liang，Y. B. (梁玉波) and Wang，B. (王斌). 2001. Alien marine species and their impacts in China. Biodiversity Science (生物多样性), 9: 458-465. (in Chinese with English abstract)

Lovei, G. L. 1997. Biodiversity-global change through invasion. Nature, 388: $627-628$.

Ma，Y. Q. (马逸清). 1980. The distribution and resources of muskrat in Heilongjiang Province. Research on Natural Resources (自然资源研究), (3) : 78-83. (in Chinese)

Miao, Z. W. (苗振旺). 2001. Study on the biological characteristics of Dendroctonus valens. Shanxi Forestry Science and Technology (山西林业科技), (1)：34-37. (in Chinese with English abstract)

Pan, W. Y. (潘务耀), Tang, Z. Y. (唐子颖) and Yu, H. B. (余海滨). 1995. Research on the loblolly pine mealy bug (Oracella acutus) newly invaded into China. Forest Re- 
search (林业科学研究), (8): 67-72. (in Chinese with English abstract)

Pang, X. F. (庞雄飞) and Tang, C. (汤才). 1994. The prevention and control of new invaded pest loblolly pine mealy bug (Oracella acutus). Forest Pest and Disease (森林病虫 通讯),(2): 32 -34. (in Chinese)

Peng, S. L. (彭少麟) and Xiang, Y. C. (向言词). 1999. The invasion of exotic plants and effects of ecosystems. Acta Ecologica Sinica (生态学报), 19:560 - 569. (in Chinese with English abstract)

Pimentel, D., Lach, L., Zuniga, R. and Morrison, D. 2000. Environmental and economic costs of non-indigenous species in the United States. BioScience, 50: $53-65$.

Qiang, S. (强胜) and Cao, X. Z. (曹学章). 2000. Survey and analysis of exotic weeds in China. Journal of Plant Resources and Environment (植物资源与环境), 9(4)：3138. (in Chinese with English abstract)

Qiang, S. (强胜) and Cao, X. Z. (曹学章). 2001. Harmfulness of exotic weeds in China and for their management. Biodiversity Science (生物多样性), 9: 188 - 195. (in Chinese with English abstract)

Qu, B. X. (屈邦选). 1987. Study on the forecast of fall webworm (Hyphantria cunea). Journal of Northwest Forestry College (西北林学院学报), 2(2)：41 - 49. ( in Chinese with English abstract)

Song, Y. S. (宋玉双). 2000. Pest risk analysis of red turpentine beetle (Dendroctonus valens). Forest Pest and Disease (森林病虫通讯), (6): 34-36. (in Chinese)

State Oceanic Administration (国家海洋局). 2001. Report of disaster of red tide in coasts of China in 2000. In: State Oceanic Administration (国家海洋局) (ed. ), China Marine Stastistics Year Book (中国海洋统计年鉴). Ocean Press, Beijing. (in Chinese)

Wan, F. H. (万方浩), Guo, J. Y. (郭建英) and Wang, D. H. (王德辉). 2002. Alien invasive species in China: their damages and management strategies. Biodiversity Science (生物多样性), 10: 119 -125. (in Chinese with English abstract)

Wu, Z. P. (吴志平) and Cheng, K. L. (程开禄). 1995. Preliminary study on the occurrence and control of apple snail (Ampullaria canalicuat) in Sichuan Province. Plant Quarantine (植物检疫), 9 (5): 266-269. (in Chinese) Xu, C. Y. (徐承远), Zhang, W. J. (张文驹), Lu, B. R. (卢宝荣) and Chen, J. K. (陈家宽) . 2001. Progress in studies on mechanisms of biological invasion. Biodiversity Science(生物多样性), 9: 430 - 438. ( in Chinese with English abstract)

Xu, H. G. (徐海根) and Ding, H. (丁晖) . 2003. Countermeasures for the prevention of invasive alien species. In: Wang, D. H. (王德辉) and Fang, C. (方晨) ( eds.), Conserving Biodiversity and Strengthening Management of Nature Reserves (保护生物多样性：加强自然保护区管 理). China Environmental Science Press, Beijing, 128 139. ( in Chinese)

Xu, J. X. (徐家雄), Ding, K. J. (丁克军) and Situ, Z. G. (司徒尊贵). 1992. Preliminary study on biology of loblolly pine mealy bug (Oracella acutus). Guangdong Forestry Science and Technology (广东林业科技), (4)：21-24. (in Chinese)

Xu, R. Q. (许瑞秋). 1997. The new harmful farmland animal nutria. Plant Protection (植物保护), 23(5): 46-47. (in Chinese with English abstract)

Ye, W. M. (叶为民). 1993. The morphology of pine wood nematode. Animal and Plant Quarantine (动植物检疫), 1: 14 - 16. ( in Chinese with English abstract)

Yin, H. F. (殷惠芬). 2000. The morphological and biological characteristics of red turpentine bark beetle. Acta Zootaxonomica Sinica (动物分类学报), 25: 120 -121. (in Chinese with English abstract)

Zhang, L. Y. (张林艳) and Ye, W. H. (叶万辉). 2002. Community invasibility and its influencing factors. Acta Phytoecologica Sinica (植物生态学报), 26: 109 - 114 . (in Chinese with English abstract)

Zhang, S. H. (张硕慧). 2002. Discussion on the mechanisms of non-indigenous species transfer via ships's ballast water. Navigation of China (中国航海)，(1): 43 - 47. (in Chinese with English abstract)

Zheng, H. Y. (郑汉业). 1979. The population dynamics and biological control of pine bast scale. Acta Entomologica Sinica (昆虫学报)，22: 149 - 155. ( in Chinese with English abstract)

Zhu, J. (朱靖) and Yan, Z. T. (严志堂). 1964. The habitat and density of muskrat. Acta Zoologica Sinica (动物学 报), 16: 354 - 371. (in Chinese with English abstract)

Zhu, J. (朱靖) and Yan, Z. T. (严志堂). 1965. The foods and food bases of muskrat. Acta Zoologica Sinica (动物学 报), 17: 352 - 363. ( in Chinese with English abstract) 
附录 1 中国 100 种主要外来入侵物种名录

Appendix 1 Namelist of 100 alien invasive species in China

名称 Species

所属类别 Category

I . 微生物 Microorganism

1) 大豆疫病菌 Phytophthora megasperma

2 ) 马铃薯癌肿病菌 Synchytrium endobioticum

3 ) 番茄细菌性溃疡病菌 Clavibater michiganensis

4 ) 水稻条斑病菌 Xanthomonas oryzae

5 ）桉树青枯病菌 Pseudomonas solanacearum

6 ）棉花黄萎病菌 Verticillium dahliae

7 ) 烟草环斑病毒 Tobacco ring spot virus

8 ）落叶松枯梢病菌 Botryosphaeria laricina

9) 松针红斑病菌 Mycosphaerella pini

10）甘薯长喙壳菌 Ceratocystis fimbriata

II. 水生植物 Aquatic plant

11 ) 洞刺角刺藻 Chaetoceros concavicornis

12 ）新月圆柱藻 Cyclindrotheca closterium

13 ) 微型原甲藻 Prorocentrum minimum

14 ）反屈原甲藻 P. sigmoides

15 ) 斯氏梨形藻 Scrippsiella trochoidea

16）空心莲子草 Alternanthera philoxcroides

17 ) 互花米草 Spartina alterniflora

18 ）大米草 $S$. anglica

19）凤眼莲 Eichhornia crassipes

III. 陆生植物 Terrestrial plant

20 ) 刺花莲子草 Alternanthera pungens

21 ）反枝范 Amaranthus retroflexus

22 ) 刺苋 A. spinosus

23 ）美洲商陆 Phytolacca americana

24 ) 王不留行 Vaccaria segetalis

25 ）土荆芥 Chenopodium ambrosioides

26 ）杂配藜 C. hybridum

27 ) 胜红蓟 Ageratum conyzoides

28 ) 豚草 Ambrosia artemisiifolia

29 ) 三裂叶豚草 $A$. trifida

30）大狼把草 Bidens frondosa

31 ) 三叶鬼针草 B. pilosa

32 ) 野塘蒿 Conyza bonariensis

33 ) 小白酒草 C. canadensis

34 ）苏门白酒草 C. sumatrensis

35 ) 一年蓬 Erigeron annuus

36 ）紫茎泽兰 Eupatorium adenophorum

37 ) 飞机草 E. odoratum

38 ）辣子草 Galinsoga parviflora

39 ) 薇甘菊 Mikania micrantha

40 ）欧洲千里光 Senecio vulgaris

41 ）加拿大一枝黄花 Solidago canadensis

42 ) 刺苍耳 Xanthium spinosum

43 ) 圆叶甡牛 Ipomoea purpurea

腐霉科 Pythiaceae

集壸菌科 Synchytriaceae

棒形杆菌属 Clavibater

假单胞菌科 Pseudomonaceae

假单胞菌科 Pseudomonaceae

从梗狍科 Moniliaceae

豇豆花叶病毒科 Comoviridae

座囊菌科 Dothideaceae

黑盘狍科 Melanconiaceae

长喙霉科 Ceratocystiaceae

硅藻门 Bacillariophyta

硅藻门 Bacillariophyta

甲藻门 Pyrrophyta

甲藻门 Pyrrophyta

甲藻门 Pyrrophyta

苋科 Amaranthaceae

禾本科 Gramineae

禾本科 Gramineae

雨久花科 Pontederiaceae

苋科 Amaranthaceae

苋科 Amaranthaceae

苋科 Amaranthaceae

商陆科 Phytolaccaceae

石竹科 Caryophyllaceae

萩科 Chenopodiaceae

僽科 Chenopodiaceae

菊科 Compositae

菊科 Compositae

菊科 Compositae

菊科 Compositae

菊科 Compositae

菊科 Compositae

菊科 Compositae

菊科 Compositae

菊科 Compositae

菊科 Compositae

菊科 Compositae

菊科 Compositae

菊科 Compositae

菊科 Compositae

菊科 Compositae

菊科 Compositae

旋花科 Convolvulaceae 
附录 1 (续) Appendix 1 (continued)

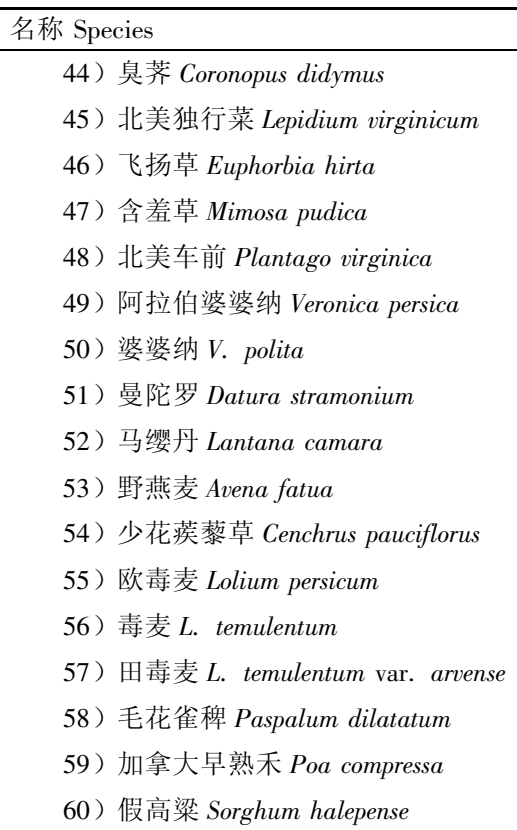

IV. 水生无脊椎动物 Aquatic invertebrate
61 ) 福寿螺 Pomacea canaliculata
62）克氏原鳌虾 Procambarus clarkii
63）华美盘管虫 Hydroides elegans
64 ）沙饰贝 Mytilopsis sallei
65）指甲履螺 Crepidula onyx
66 ) 纹藤吉 Balanus amphitrite
67 ) 象牙藤壶 $B$. eburneus
68 ）苔藓虫 Bryozoa
69）玻璃海鞘 Ciona intestinalis
70 ）曼氏皮海鞘 Molgula manhattensis
71 ) 冠瘤海鞘 Styela canopus

V. 陆生无脊椎动物 Terrestrial invertebrate

72）松材线虫 Bursaphelenchus xylophilus

73 ) 日本松干蚧 Matsucoccus matsumurae

74）松突圆蚧 Hemiberlesia pitysophila

75）湿地松粉蚧 Oracella acuta

76）苹果绵蚜 Eriosoma lanigerum

77) 二斑叶螨 Tetranychus urticae

78 ）巴西豆象 Zabrotes subfasciatus

79 ）谷斑皮冨 Trogoderma granarium

$80 ）$ 马铃薯甲虫 Leptinotarsa decemlineata

81 ) 稻水象甲 Lissorhoptrus oryzophilus

82）美洲斑潜蝇 Liriomyza sativae

83 ）蔗扁蛾 Opogona sacchari

84）烟粉虫 Bemisia tabaci

85 ）温室白粉風 Trialeurodes vaporariorum

86）苹果蠹蛾 Laspeyresia pomonella

87）美国白蛾 Hyphantria cunea

88）红脂大小冨 Dendroctonus valens
所属类别 Category

十字花科 Cruciferae

十字花科 Cruciferae

大戟科 Euphorbiaceae

豆科 Leguminosae

车前科 Plantaginaceae

玄参科 Scrophulariaceae

玄参科 Scrophulariaceae

茄科 Solanaceae

马鞭草科 Verbenaceae

禾本科 Gramineae

禾本科 Gramineae

禾本科 Gramineae

禾本科 Gramineae

禾本科 Gramineae

禾本科 Gramineae

禾本科 Gramineae

禾本科 Gramineae

瓶螺科 Ampullariidae

蝲蛄科 Astacidae

龙介虫科 Serpulidae

饰贝科 Dreissenidae

帆螺科 Calyptraeidae

藤壶科 Balanidae

藤壸科 Balanidae

苔藓动物门 Bryozoa

玻璃海鞘科 Cionidae

皮海鞘科 Molgulidae

瘤海鞘科 Styelidae

滑刃科 Aphelenchoididae

珠蚧科 Margarodidae

盾蚧科 Diaspididae

粉蚧科 Pseudococcidae

瘞绵蚜科 Pemphigidae

叶螨科 Tetranychidae

豆象科 Bruchidae

皮蠹科 Dermestidae

叶甲科 Chrysomelidae

象甲科 Curculionidae

潜蝇科 Agromyzidae

辉蛾科 Hieroxestidae

粉禹科 Aleyrodidae

粉禹科 Aleyrodidae

卷蛾科 Tortricidae

灯蛾科 Arctiidae

小冨科 Scolytidae 
附录 1 (续) Appendix 1 (continued)

名称 Species

所属类别 Category

89 ）美洲大蠊 Periplaneta americana

蜚蠊科 Blattidae

90 ）非洲大蜗牛 Achatina fulica

玛瑙螺科 Achatinidae

VI. 两栖爬行类 Amphibian and reptile

91 ) 牛蛙 Rana (Aquarana) catesbeiana

蛙科 Ranidae

92 ）河蛙 R. (Aquarana) heckscheri

蛙科 Ranidae

VII. 鱼类 Fish

93 ）大口黑鲈 Micropterus salmoides

94 ) 奥利亚罗非鱼 Oreochromis aureus

太阳鱼科 Ceutrarchidae

95 ) 尼罗罗非鱼 $O$. nilotica

丽鱼科 Cichlidae

96 ）食蚊鱼 Gambusia affinis

丽鱼科 Cichlidae

胎鳞科 Poeciliidae

VIII. 哺乳类 Mammal

97 ) 小家鼠 Mus musculus

鼠科 Muridae

98 ）噟鼠 Ondatra zibethica

鼠科 Muridae

99 ) 褐家鼠 Rattus norvegicus norvegicus

鼠科 Muridae

100 ) 獭狸 Myocastor coypus

海狸科 Myocastoridae 